Selcuk Journal of Agriculture and Food Sciences

http://sjafs.selcuk.edu.tr/sjafs/index

Research Article
SJAFS

(2019) 33 (1), 26-36

e-ISSN: $2458-8377$

DOI:10.15316/SJAFS.2019.152

\title{
Determination of Cold Resistance of Buds and Flowers on Kütahya Sour Cherry Cultivar
}

Omar Mohammed Ghanim ALNUAIMI ${ }^{1 *}$, Lütfi PIRLAK ${ }^{1}$

${ }^{1}$ Selçuk University, Faculty of Agriculture, Department of Horticulture, Konya, Turkey

\begin{tabular}{l}
\hline ARTICLE INFO \\
\hline Article history: \\
Received date: 22.02 .2019 \\
Accepted date: 15.03 .2019 \\
\hline Edited by: \\
Ali SABIR; Selçuk University, Turkey \\
Reviewed by: \\
Halil İbrahim OĞUZ; Nevşehir Hact \\
Bektaş Veli University, Turkey \\
Ahmet EŞiTKEN; Selcuk University, \\
Turkey
\end{tabular}

Keywords:

Kütahya Sour Cherry Variety

Flower Buds

Flowers

Cold Resistance

\begin{abstract}
This study was carried out in 2018 in order to determine the resistance of flower buds and flowers to low temperatures in winter and spring periods in Kütahya sour cherry cultivar, in Konya's conditions. In order to determine the temperature of the flower buds and flowers, the samples taken at different periods were gradually placed in the temperature-lowered cabinet and tested. The buds were tested, held at temperatures between 0 and $-22^{\circ} \mathrm{C}$. After the application, $70 \%$ or above of damaged buds were considered dead. In addition, total, bound and free water, dry matter, total carbohydrate, protein, proline and nutrient levels were determined. Differences between the mortality rates of buds and flowers at different temperatures were statistically significant. In the winter season, buds with high frost resistance started to lose this resistance towards the spring season. Temperatures of more than $50 \%$ of buds are observed at $-16^{\circ} \mathrm{C}$ on $29.01 ; 20.02$ and 06.03 at $-15^{\circ} \mathrm{C} ; 20.03$ at $-11^{\circ} \mathrm{C}$; it was determined as $-10^{\circ} \mathrm{C}$ on 05.04 and 20.04 . According to this, in the city center of Konya cherry flower buds are damaged by frost until the end of March and the probability of damage after this period is reduced. With the emergence of winter season, the water content of the buds has increased significantly. A rapid decrease in the amount of bound water was found in the buds with the emergence of winter and a rapid increase in the amount of free water. On the other hand, the dry matter contents remained stable between 29.01 and 05.03 , and a rapid increase occurred on 19.03. The differences between the nutrient amounts were found to be statistically significant. According to this, the content of $\mathrm{N}$ in buds has decreased continuously between 29.01 and 20.04. The amounts of $\mathrm{P}, \mathrm{K}, \mathrm{Mn}, \mathrm{Zn}$ and S increased from 29.01 to 20.03 and started to decrease after this date. $\mathrm{Mg}$ and $\mathrm{Fe}$ amounts increased regularly until 20.03 and remained stable after this date. $\mathrm{Ca}$ and $\mathrm{Cu}$ levels increased until 06.03, then began to fall. The B content increased continuously. The amount of $\mathrm{Zn}$ increased regularly until 05.04 and then decreased. S content fluctuated on different dates. Significant differences were determined in terms of carbohydrate content in buds. According to this, the carbohydrate content decreased regularly from 29.01 until 05.04 and started to rise again in 19.04. Bud's protein contents showed a steady decrease in successive sampling periods. The differences between the contents of the proline were not statistically significant.
\end{abstract}

\section{Introduction}

Sour cherry (Prunus cerasus L.) is a member of the Rosaceae family. The origin of the sour cherry is the North Anatolian Mountains stretching between Asia, Istanbul and the Caspian Sea. Sour cherry Cherry is well adapted to different climatic conditions. The continental climate prevailing in the inner regions of Anatolia is based on hot and dry summers and cold winters. For this reason, it is mostly grown in the inner and transition regions of Anatolia (Özçağıran et al., 2003).

\footnotetext{
* Corresponding author email: pirlak@selcuk.edu.tr
}

The world sour cherry production is 1,378,216 tons, 192.500 tons with Turkey ranks 3rd after Russia and Poland (FAO, 2018). The province which is the first in the cherry production in our country is Afyonkarahisar and then it comes from Kütahya, Konya, Ankara and Isparta (Tuik, 2018). Low temperature is considered to be the most important factor determining the distribution of plant species on the earth and may limit the yield and distribution of horticultural crops (Kalberer et al., 2006). Gardeners are constantly confronted with the problem of cold tolerance in relation to high quality fruit production (Nybom, 1992). The resistance of fruit trees to cold is primarily affected by genotype. Critical 
temperatures that damage reproductive organs are different between species and varieties. However, it is not easy to distinguish genotype effects from other factors. As a result, it has been observed that critical temperatures change not only with the phenological stage of flower buds but also with species, cultivars, orchards and even trees (Westwood, 1993).

While the flower buds of the fruit trees are resistant to the low temperature effects, in the spring after the rest, the dormancy period ends, the plants begin to grow and the resistance to cold decreases (Iezzoni and Hamilton, 1985). Damage to open generative buds and ovaries depends not only on temperature but also on freezing time. Data on factors determining the resistance and resistance of sour cherry generative organs to spring frosts are insufficient. The aim of this study was to investigate the resistance of sour cherry buds and flowers to winter and spring frosts.

Due to the climate zone in which our country is located, fruit species are sometimes damaged by spring frosts. Previously, these damages were more common in early flowering almonds, apricot and peach fruit species, but in recent years they caused losses in late flowering fruit species due to global climate change. In the observations made in Central Anatolia and Konya province, spring frosts have been found to cause damage in late blooming fruit species such as apple, pear, quince and sour cherry in recent years.

By determining the types and varieties of fruit suitable for the regions, it may be possible to reduce the frost damage that constitutes a financial burden on the producers, the country's economy and the institutions and organizations insuring agricultural products. For this purpose, it is possible to determine the variety and variety of fruit species and varieties suitable for each region by determining the susceptibility of the fruits species and varieties to the cold in different phenological periods. Thus, the effect of frost events that lead to large yield losses can be reduced to a certain extent. The aim of this study is to determine the cold tolerance of buds and flowers in cherries which are an important part of our country's agriculture and to examine some factors affecting cold tolerance.

\section{Materials and Methods}

\subsection{Materials}

The research was conducted in 2018 in the Department of Horticulture, Faculty of Agriculture, Selçuk University. At 13 years of age, Kütahya sour cherry cultivar were used as the plant material. Kütahya sour cherry variety is the most important cherry variety of our country. Flowers in April-May. The leaves are bright, glabrous and short-handled. The fruit is shiny dark red, roundish in heart shape and the end side is cut. Juicy and flavored. Very good quality. Trees are very efficient (Özçağıran et al., 2003).

\subsection{Methods}

Studies and practices were made on the shoots taken from the plants in the fruit-making period and under the same climate and maintenance conditions. Exemplary plants are inoculated on the same rootstock, the same age and size. 25 plants were selected from Kütahya sour cherry cultivar and samples were taken from these plants. The study was carried out to cover 1 winter and spring period, and samples were taken every 15 days (Felipe, 1977). Specimens were taken from the middle of the trees at a height of at least $1 \mathrm{~m}$ from the ground and between 10-11 in the morning (Pramsohler and Neuner, 2013). The samples were taken as much as possible from the same regions of all trees and with the same length. The samples were kept at a temperature of $+4^{\circ} \mathrm{C}$ (Quamme, 1983) in order not to change the exothermic temperature until the application time of cold application (Quamme, 1983). In each period, frost and vitality tests, in order to determine the organic and inorganic substances 300 flower bud and flower was taken.

\section{Determination of the Temperature at which the Buds Die}

In order to determine the temperature of the flower budsand flowers, the samples taken at different periods were gradually placed in the temperature-lowered cabinet and tested. The buds were placed in aluminum foil to prevent the buds from being affected by temperature fluctuations during testing (Wheeler et al., 2014). The test buds and flowers were made at temperatures between 0 and $-22^{\circ} \mathrm{C}$ for 1 hour (Reig et al., 2013). After the application, $70 \%$ of damaged buds were considered dead. Damage detection was done by cutting the buds. The color of the buds was taken as cross section, the light yellow and green ones were alive, and their color was darkened and returned to brown (Felipe, 1977; Reig et al., 2013).

Determination of Total, Bouned and Free Water Quantities

Fresh weight, air dried and oven dry weights were taken from 50 buds taken at each stage. The obtained values were processed in the following formulas and thus, the free, bound and total water contents of flower buds and flowers were determined (Buchner and Neuner, 2011).

Total Water Amount $=($ Fresh Weight - Oven Dry $) /$ Oven Dry

Amount of Bound Water $=($ Air Dry - Oven Dry $) /$ Oven Dry

Free Water $=$ Total Water Amount - Bound Water Amount

\section{Total Dry Matter Determination}

In order to determine the dry matter ratios of the buds and flowers, 50 buds and flower were taken from different points of the shoot and dried in the oven set to a temperature of $70^{\circ} \mathrm{C}$ until complete drying was achieved (Reig et al., 2013). 


\section{Plant Nutrient Determination}

For plant nutrient analysis, 100 buds and flowers were dried at room temperature. Then, in the samples which were pulverized using mortar, analysis was performed to determine the amounts of nitrogen, phosphorus, potassium, calcium, sulfur, boron, iron, copper, zinc, manganese, magnesium and molybdenum. P, K, $\mathrm{Ca}, \mathrm{Mg}, \mathrm{Fe}, \mathrm{Mn}, \mathrm{Zn}, \mathrm{Cu}, \mathrm{B}$ and $\mathrm{S}$ contents of plant samples in 3 different steps with nitric acid-hydrogen peroxide (2: 3 ) acid:

1 st step; $75 \%$ at $145^{\circ} \mathrm{C}$ at microwave power for $5 \mathrm{~m}$. 2nd step; $90 \%$ at $180^{\circ} \mathrm{C}$ at microwave power for $10 \mathrm{~m}$. 3rd step; $40 \%$ at $100^{\circ} \mathrm{C}$ at microwave power for $10 \mathrm{~m}$.

For 40 bar pressure resistant microwave was kept in the incineration unit, $\mathrm{P}, \mathrm{K}, \mathrm{Ca}, \mathrm{Mg}, \mathrm{Fe}, \mathrm{Mn}, \mathrm{Zn}, \mathrm{Cu}$, $\mathrm{B}$ and $\mathrm{S}$ were determined by spectrophotometer, $\mathrm{N}$ determination was determined by micro Kjeldahl method (Mertens, 2005).

\section{Total Carbohydrate Determination}

Total carbohydrate analysis was performed according to Daniels et al. (2007). To this end, dry bud samples $(0.1 \mathrm{~g})$ were placed in a test tube in a $10-5 \mathrm{ml}$ $\mathrm{NaOH}$ water bath. After 10 minutes, $5 \mathrm{ml}$ of distilled water was added and the protein content was obtained. The residues were washed with water and extracted twice with $10 \mathrm{ml}$ of $67 \% \mathrm{H} 2 \mathrm{SO} 4$ for $30 \mathrm{~min}$ at room temperature. Appropriate dilution of the samples was carried out and the diluted samples filtered. To $1 \mathrm{ml}$ sample, $1 \mathrm{ml}$ phenol $5 \%$ reagent was added and then 5 ml concentrated. $\mathrm{H} 2 \mathrm{SO} 4$ was mixed with the sample and allowed to stand at room temperature for 30 minutes. The resulting color was measured at $490 \mathrm{~nm}$ using a spectrophotometer against a reactive paper and the total carbohydrates were calculated using the standard glucose curve.

\section{Protein Determination}

Protein determination was made according to the Bradford method using $0.5 \mathrm{~g}$ samples where taken from the plant's buds. The results were calculated in terms of edil (mg protein / g) fresh texture. In each treatment plant, where $0.5 \mathrm{~g}$ of the small fragmented organs was taken and 10 pieces homogenisation was performed by crushing it in $0.05 \mathrm{M}$ phosphate buffer ( $\mathrm{pH}$ : 6.5 ). The homogenate was filtered through a four-layered web and the filtrate was taken to centrifuge tubes and centrifuged at 15,000 rpm for $20 \mathrm{~min}$. The liquid phase (supernatant) at the top of the tubes was used for protein determination and the amount of protein was determined by spectrophotometric method (Brasford, 1976).

\section{Proline Determination}

Proline determination was determined spectrophotometrically by acid-ninhydrin method (Bates et al., 1973). A standard graph was drawn using pure proline for this process. From the stock solution containing 200 $\mu \mathrm{g}$ of proline in $1 \mathrm{ml}$ to the tubes, $0.2,0.4,0.6,0.8,1.0$, $1.2,1.4,1.6,1.8$ and $2.0 \mathrm{ml}$ of each tube was taken up to $2 \mathrm{ml}$ with distilled water. $2 \mathrm{ml}$ of glacial acetic acid and $2 \mathrm{ml}$ of acid-ninhydrin solution were then added to the tubes. These samples were taken immediately to a $100^{\circ} \mathrm{C}$. After 1 hour, the reaction was stopped by keeping in an ice bath for $10 \mathrm{~min} .4 \mathrm{ml}$ of toluene were added to each tube and mixed with a vortex for 20-30 sec. Then, in each tube, the supernatant was taken by an automatic pipette and the absorbance at $520 \mathrm{~nm}$ was measured. The standard graph is plotted using these values. For the determination of proline in the samples, $0.1 \mathrm{~g}$ of texture was homogenized in a porcelain mortar in $10 \mathrm{ml}$ of $3 \%$ sulfosalicylic acid and filtered through a funnel. $2 \mathrm{ml}$ of the filtrate was taken and processed for the above standard graph. Then, A520 values obtained were determined as lerig proline on standard graph. These values were replaced with the following formula and calculated as ( $\mu$ molar / g fresh leaf) proline.

Proline $(\mu \mathrm{M}) /$ Fresh Leaf $(\mathrm{g})=($ Proline $(\mu \mathrm{M}) / \mathrm{ml} \mathrm{x}$ $\mathrm{ml}$ toluene) / (115.5 $\mu \mathrm{g} / \mathrm{mM}) /(\mathrm{g}$ texture/ 5)

\section{Results and Discussion}

Determination of the Temperature at which the Buds and flowers die

The results of the mortality rates of sour cherry bud and flower samples taken at different times between 0 $-22^{\circ} \mathrm{C}$ are given in Table 1 . The differences between the mortality rates of buds and flowers at different temperatures were found to be statistically significant in all bud intake periods. The resistance of the buds and flowers to the cold varies according to their development period. This is entirely due to metabolic changes in the plant. For example, the rate of sugar in the resting cells and the increase of proteins increase the frost resistance by decreasing the formation of ice in the cell (Küden et al., 1998). Accordingly, in the samples taken at 29.01 , there was no death between 0 and $-9^{\circ} \mathrm{C}$. From $-10^{\circ} \mathrm{C}$, buds began to die; mortality rates from -10 to $12^{\circ} \mathrm{C}$ where $\% 1$ only dead; $-13^{\circ} \mathrm{C}$ where $\% 3 ;-14^{\circ} \mathrm{C}$ where $\% 8 ;-15^{\circ} \mathrm{C}$ where $\% 49 ;-16^{\circ} \mathrm{C}$ where $\% 97$; $17^{\circ} \mathrm{C}$ where $\% 99$ and finally at $-18^{\circ} \mathrm{C}$ all buds where $\% 100$ dead. In the samples taken at 20.02, there was no death until $-11^{\circ} \mathrm{C}$. Death occurred in buds from $11^{\circ} \mathrm{C}$; mortality rates at $-11^{\circ} \mathrm{C}$ where $\% 1 ;-12^{\circ} \mathrm{C}$ where $\% 2 ;-13^{\circ} \mathrm{C}$ where $\% 18 ;-14$ and $-15^{\circ} \mathrm{C}$ where $\% 77$; $16^{\circ} \mathrm{C}$ all buds where $\% 100$ dead. In the samples taken at 06.03 , there was no death up to $-7^{\circ} \mathrm{C}$. Mortality rates were -8 and $-9^{\circ} \mathrm{C}$ where $\% 2 ;-10^{\circ} \mathrm{C}$ where $\% 3 ;-11^{\circ} \mathrm{C}$ where $\% 16 ;-12$ and $-13^{\circ} \mathrm{C}$ where $\% 18 ;-14^{\circ} \mathrm{C}$ where $\% 31 ;-16^{\circ} \mathrm{C}$ where $\% 78 ;-18^{\circ} \mathrm{C}$ all buds where $\% 100$ dead. In the samples taken at 20.03, there was no death between 0 and $-5^{\circ} \mathrm{C}$. From $-6^{\circ} \mathrm{C}$, buds began to die $\%$ 1 ; mortality rates from $-7^{\circ} \mathrm{C}$ where $\% 7 ;-8^{\circ} \mathrm{C}$ where $\%$ $15 ;-9^{\circ} \mathrm{C}$ where $\% 34 ;-10^{\circ} \mathrm{C}$ where $\% 50 ;-11^{\circ} \mathrm{C}$ where $\% 51 ;-12^{\circ} \mathrm{C}$ where $\% 65 ;-13^{\circ} \mathrm{C}$ where $\% 92 ;-14^{\circ} \mathrm{C}$ all buds where $\% 100$ dead.

The accuracy of buds to frost continued to increase in 05.04. As a matter of fact, the first damage tempera- 
ture in the buds taken in this period is $-4^{\circ} \mathrm{C}(1 \%$ death). As the temperature drops, the rate of damage has increased. Mortality rates are $-5^{\circ} \mathrm{C}$ where $\% 2 ;-6^{\circ} \mathrm{C}$ where $\% 3 ;-7^{\circ} \mathrm{C}$ where $\% 8 ;-8^{\circ} \mathrm{C}$ where $\% 10 ;-9^{\circ} \mathrm{C}$ where $\% 34 ;-10^{\circ} \mathrm{C}$ where $\% 67 ;-11^{\circ} \mathrm{C}$ where $\% 90$; $12^{\circ} \mathrm{C}$ all buds where $\% 100$ dead. In the samples taken on 20.04 , the first damage occurred at $-4^{\circ} \mathrm{C}(9 \%$ death). Mortality rates are $-6^{\circ} \mathrm{C}$ where $\% 13 ;-7^{\circ} \mathrm{C}$ where $\% 16 ;-8^{\circ} \mathrm{C}$ where $\% 24 ;-9^{\circ} \mathrm{C}$ where $\% 31$; $10^{\circ} \mathrm{C}$ where $\% 52 ;-11^{\circ} \mathrm{C}$ where $\% 93$; after this temperature all buds where $\% 100$ dead. (Table 1).

With the decrease in the temperature in all sampling periods, the mortality rates of the buds have increased and this is an expected result. Similar results were obtained in the studies on the subject (Andrews and Proebsting 1987; Bartolini et al., 2001; Bartolozzi and Fontananza 1999; Burak 1989; Demirel 1997; Ertürk and Güleryüz, 2007).

In addition, buds with high frost resistance in winter started to lose this endurance towards spring season. This is a natural consequence of the warming of The atmosphere, while the buds waking up with water mobility. It is accepted that at least $50 \%$ of the flower buds should remain healthy for a safe product. More than $50 \%$ damage occurring temperatures, 29.01 where $-16^{\circ} \mathrm{C}, 20.02$ where $-14^{\circ} \mathrm{C}, 06.03$ where $-16^{\circ} \mathrm{C}, 20.03$, 05.04 and 20.04 where $-10^{\circ} \mathrm{C}$ that been proved. In previous studies on temperate climate fruit species, frost resistance increased to the middle of winter and reached the highest level, and then began to decrease (Burak 1989; Demirel 1997; Aslantaş 1999).

According to the data of long years in Konya city center (1 January - 30 April), the lowest temperature values are given in Table 2 and 3. According to this, the sour cherry buds in the city center of Konya are damaged by frost in January. As a matter of fact, in our study, it was found that the samples taken on 29.01 were more than $50 \%$ damage from $-15^{\circ} \mathrm{C}$. According to the data of many years, there is a possibility that the temperature will fall below $-15^{\circ} \mathrm{C}$ in every day of January in Konya city center (Table 2 and 3 ).

Likewise, there is a possibility of damaging the buds in February. In the samples taken at 20.02, more than $77 \%$ death was detected after $-14^{\circ} \mathrm{C}$. According to long-term data, the temperature for 14 days was lower than $-14^{\circ} \mathrm{C}$ until the 20th of February. The buds received on 06.03 were started at $-8^{\circ} \mathrm{C}$. However, these mortality rates were below $50 \%$ at $-17^{\circ} \mathrm{C}$, and this rate was $87 \%$. In the city center of Konya between 20 February and 6 March the temperature has fallen under $17^{\circ} \mathrm{C}$ for 4 days. As a result, the likelihood of damage to sour cherry buds in the period mentioned is still continuing. In the samples taken at 20.03, more than $50 \%$ damage occurred below $-10^{\circ} \mathrm{C}$. According to the meteorological data, it is also possible to damage the sour cherry buds during this period. Because the temperatures were below $-10^{\circ} \mathrm{C}$ for 8 days. In the samples taken on 05.04 , the rate of damage below $-10^{\circ} \mathrm{C}$ exceeded $50 \%$. During this period, as the weather contin- ued to warm up to $-10^{\circ} \mathrm{C}$, the number of days was reduced to 3 , so the likelihood of damage to the buds was reduced. Significant damages have occurred from $10^{\circ} \mathrm{C}$ in the samples taken on 20.04 . According to the data of many years in the city center of Konya between 5-20 April, the temperature did not fall below $-10^{\circ} \mathrm{C}$. Accordingly, there is no risk of damage to cherry buds between these dates.

\section{Total, Bound, Free Water and Dry Matter Amount in} Buds

Water and dry matter contents of sour cherry buds in different periods are given in Table 4. As a results, the differences between water and dry matter contents of buds in different periods were found to be statistically significant. While the total water content in the buds was $86.60 \%$ in 29.01 , it increased to $86.55 \%$ in 19.02 , $87.50 \%$ in 05.03 and $97.74 \%$ in 19.03 . Accordingly, it is evident that the water content in the buds increases with the emergence from the winter season. This is expected as a result of the warming of the atmosfer, consequently the arousal and growth of the buds. The water condition in plant texture generally indicates the frost damage potential. Frost damage occurs as a result of dehydration of plant cells related to freezing (Xin and Browse, 2000) and plant texture with high water content are more damaged by freezing (Hao et al., 2009).

A rapid decrease in the amount of bound water was found in the buds with the emergence of winter and a rapid increase in the amount of free water. The bound water, which was $0.084 \mathrm{mg}$ on 29.01 , fell to 0.080 in $19.02,0.051$ in 05.03 and $0.027 \mathrm{mg}$ in 19.03. On the other hand, the bound water, which was $0.666 \mathrm{mg}$ on 29.01, increased to 0.757 in 19.02 , to 0.964 in 05.03 and to $1.879 \mathrm{mg}$ on 19.03. Similarly, in the study conducted by Ertürk and Güleryüz (2007), it was determined that water content of buds increased from winter to spring and there was a negative correlation between water content and frost resistance. Increased water content in texture reduces the frost resistance of texture and increases the threat of damage. The higher the amount of water in the texture, the greater the durability. The cold acclimation period promotes the depletion of water in tissues as well as the accumulation of osmotically inactive protein and starch. As a result, a smaller amount of water in the tissues of the plants can provide a significant advantage for adaptation. In this way, less expansion and deterioration may occur in the intercellular spaces (Levitt, 1980).

The dry matter contents of the buds obtained at different dates were found to be almost the same between 29.01 and 05.03 and a rapid decrease was observed in 19.03. The flower buds that pass during the winter rest awaken with the warming of the weather in the spring. In this awakening, with the warming of the atmosfer, the movement of water in the soil and in the plant has an effect. With the movement of water in the plant, the stored nutrients move rapidly towards the buds. The amount of water and dry matter in the buds varied in 
the opposite direction to each other. With the increase of water, frost sensitivity is increased, buds gain more frost sensitivity strength with dry matter increase. Likewise, Aslantaş (1999) found a positive correlation between dry matter and almond resistance in almond buds.

\section{Plant Nutrient Determination}

Nutrient element analysis results of cherry buds taken at different dates are given in Table 5. The differences between the nutrient amounts were found to be statistically significant. According to this, the content of $\mathrm{N}$ in buds has decreased continuously between 29.01 and 20.04. Accordingly, P, K, Mn, Zn and S amounts increased from 29.01 to 20.03 , and have started to decrease after this date. $\mathrm{Mg}$ and Fe amounts increased regularly until 20.03 and remained stable after this date. $\mathrm{Ca}$ and $\mathrm{Cu}$ levels increased until 06.03, then began to fall. The B content increased continuously. On 20.04 increased to $178 \mathrm{mg} / \mathrm{kg}$. The amount of Zn increased regularly until 05.04 and then decreased. S content fluctuated on different dates. It was increased on 19.04 and started to decrease after this date. The $\mathrm{N}$ content, on the other hand, showed a constant decrease from the other elements.

Ion loss was determined in the cells as a result of freezing / thawing stress and this caused loss of membrane permeability. The main cation that disappeared from the doner cells is potassium (Aslantaş et al., 2010). With the exposure to low temperatures, the amount of calcium in the textures increases temporarily (Puhakainen, 2004). In this process, calcium transition from apoplast to cytoplase fluid occurs. The calcium channels in the plasma membranes serve as sensors against temperature drop (Smallwood and Bowles, 2002). In plants exposed to low temperatures, cell membrane fluidity decreases. This has been shown to be a signal for the functioning of cold-stimulated genes. Yigit and Güleryüz (1995) investigated the effects of potassium fertilization on cold resistance in Kütahya sour cherry variety. The potency of potassium in plants increases by affecting carbohydrate metabolism. determined that the potassium fertilizers applied at the appropriate doses lower the freezing point to lower temperatures by increasing sugar accumulation and osmotic pressure in the plant textures.

\section{Total Carbohydrate, Protein and Proline Amount}

Table 6 shows the total carbohydrate content of buds taken at different dates. Significant differences were determined in terms of carbohydrate content. According to this, the carbohydrate content decreased regularly from 29.01 until 04.04 and started to rise again in 19.04. This indicates that the tank carbohydrates in the buds are spent during the opening of the buds. On the other hand, as a result of photosynthesis, the extra carbohydrate production from 19.04 can be explained by the photosynthesis.

Carbohydrates are the basic cryoprotectants for cold resistance in plants. It has been reported that carbohy- drate level increases up to 10 times during low temperature and this accumulation is effective on frost resistance (Guy, 1990). This effect is probably thought to occur when carbohydrates pull deadly intracellular freezing point to lower degrees. These substances also prepare the cells to tolerate freezing by acting as osmoprotectant to prevent dehydration from cytoplasm (Smirnoff, 1995). The relationship between the accumulation of carbohydrates in texture and resistance to cold was investigated in the rest period of different fruit species. In this context, Burak (1989) peach, Bolat (1993) and Demirel (1997) apricot, Palonen (1999) in the raspberry, the periodic change in carbohydrates and frost resistance have determined that there are important relationships.

Bud protein contents showed a steady decrease in successive sampling periods. The amount which was 1.423 on 29.01 decreased to 1.346 on 05.03 and to 1.215 on 19.04. This decrease is the result of the use of proteins as a source of nutrients during the opening of buds as in the total carbohydrate. Proteins play an important role in cold physiology of plants (Ertürk and Güleryüz, 2007). Many studies have shown that new polypeptides are synthesized in response to low temperatures. In recent years, studies have shown that there is a relationship between frost resistance and proteins (Aslantaş et al., 2010).

Burak (1989) stated that the high rate of protein in flower buds affects the frost resistance positively. Our results are similar to the results of Litvinova (1974), Tamássy and Zayan (1981), Burak (1989). It has important functions such as the incorporation of proteins into the membrane structure, the hydrophilic properties of water retention, the flowability of the protoplasm and its elasticity. For this reason, it is known that proteins contribute to cold resistance. The formation of ice crystals in the cell as a result of the exchange of soluble proteins is encouraged. The close relationship between soluble protein content and frost resistance is related to the increase in the amount of tRNA, mRNA and polysomes required for protein synthesis (Levitt, 1980). Proteins play a positive role in the growth of plants texture, apricots, peaches and olives were determined by the studies (Ashworth, 1983; Bartolozzi and Fontanazza, 1999; Bartolini et al., 2001). Amino acids and proteins have a role in the frost resistance physiology of plants. Generally, when the plants are exposed to low temperature, the amount of soluble protein in their bodies is increased relatively, it is stated that this rate is high in the frost resistant species and varieties and low in the non-resistant varieties (Ertürk and Güleryüz, 2007). Some of the special proteins accumulated during cold acclimation show antifreeze protein properties (Pearce, 2001). Antifreeze proteins (AFPs) have the ability to alter the shape and formation of the ice crystal and prevent the recrystallization of ice. As a result, they contribute to protecting the cells from frost damage. During the cold acclimation of barley, wheat, rye and canola, the accumulation of AFP was observed (Scebba et al., 1998). The total proline amount of buds 
taken at different dates is given in Table 6. The differences between proline content of the buds were not statistically significant. Proline, an amino acid, is synthesized and deposited in plants developed in response to many environmental stresses (Yeo and Flowers, 1989; Ashraf and $\mathrm{Wu}, 1994)$. The amount of proline increases in the stressed plants during the period of cold exposure (Hare and Cress, 1997). It has been determined that citrus plants, which have adapted to cold, accumulate 3 to 6 times more proline than un-plants
(Yelenosky, 1979). In a study by Xin (1998), 30-fold proline increase was observed in Arabidopsis plants during cold acclimation. Other stress factors also change the amount of proline. Prrlak and Eşitken (2004), in a study with strawberry varieties, reported that the amount of proline increased significantly in plants under salt stress. Obtaining different results here may be due to the fact that the genetic structures of the species are different.

Table 1

Death rates of sour cherry buds at different temperatures.

\begin{tabular}{|c|c|c|c|c|c|c|}
\hline \multirow{2}{*}{$\begin{array}{l}\text { Temperature } \\
\left({ }^{\circ} \mathrm{C}\right)\end{array}$} & \multicolumn{6}{|c|}{ Mortality rates (\%) } \\
\hline & 29.1 .2018 & 20.2 .2018 & 6.3 .2018 & 20.3 .2018 & 5.4 .2018 & 20.4 .2018 \\
\hline $0^{\circ} \mathrm{C}$ & $0 \mathrm{e}$ & $0 \mathrm{~d}$ & $0 \mathrm{f}$ & $0 \mathrm{f}$ & $0 \mathrm{~h}$ & $0 \mathrm{f}$ \\
\hline$-1^{\circ} \mathrm{C}$ & $0 \mathrm{e}$ & $0 \mathrm{~d}$ & $0 \mathrm{f}$ & $0 \mathrm{f}$ & $0 \mathrm{~h}$ & $0 \mathrm{f}$ \\
\hline$-2^{\circ} \mathrm{C}$ & $0 \mathrm{e}$ & $0 \mathrm{~d}$ & $0 \mathrm{f}$ & $0 \mathrm{f}$ & $0 \mathrm{~h}$ & $0 \mathrm{f}$ \\
\hline$-3^{\circ} \mathrm{C}$ & $0 \mathrm{e}$ & $0 \mathrm{~d}$ & $0 \mathrm{f}$ & $0 \mathrm{f}$ & $0 \mathrm{~h}$ & $0 \mathrm{f}$ \\
\hline$-4^{\circ} \mathrm{C}$ & $0 \mathrm{e}$ & $0 \mathrm{~d}$ & $0 \mathrm{f}$ & $0 \mathrm{f}$ & $1 \mathrm{~g}$ & $0 \mathrm{f}$ \\
\hline$-5^{\circ} \mathrm{C}$ & $0 \mathrm{e}$ & $0 \mathrm{~d}$ & $0 \mathrm{f}$ & $0 \mathrm{f}$ & $2 \mathrm{f}$ & $9 \mathrm{e}$ \\
\hline$-6^{\circ} \mathrm{C}$ & $0 \mathrm{e}$ & $0 \mathrm{~d}$ & $0 \mathrm{f}$ & $1 \mathrm{e}$ & $3 \mathrm{e}$ & $13 \mathrm{e}$ \\
\hline$-7^{\circ} \mathrm{C}$ & $0 \mathrm{e}$ & $0 \mathrm{~d}$ & $0 \mathrm{f}$ & $7 \mathrm{~d}$ & $8 \mathrm{~d}$ & $16 \mathrm{~d} \mathrm{e}$ \\
\hline$-8^{\circ} \mathrm{C}$ & $0 \mathrm{e}$ & $0 \mathrm{~cd}$ & $2 \mathrm{e}$ & $15 \mathrm{c}$ & $10 \mathrm{~d}$ & $24 \mathrm{c} \mathrm{d}$ \\
\hline$-9^{\circ} \mathrm{C}$ & $0 \mathrm{e}$ & $0 \mathrm{~cd}$ & $2 \mathrm{e}$ & $34 \mathrm{bc}$ & $34 \mathrm{c}$ & $31 \mathrm{c}$ \\
\hline$-10^{\circ} \mathrm{C}$ & $1 \mathrm{~d} \mathrm{e}$ & $0 \mathrm{~cd}$ & $3 \mathrm{e}$ & $50 \mathrm{~b}$ & $67 \mathrm{~b}$ & $52 \mathrm{~b}$ \\
\hline$-11^{\circ} \mathrm{C}$ & $1 \mathrm{~d} \mathrm{e}$ & $1 \mathrm{c} \mathrm{d}$ & $16 \mathrm{~d}$ & $51 \mathrm{~b}$ & $90 \mathrm{ab}$ & $93 \mathrm{ab}$ \\
\hline$-12^{\circ} \mathrm{C}$ & $1 \mathrm{~d} \mathrm{e}$ & $2 \mathrm{c}$ & $18 \mathrm{bcd}$ & $65 \mathrm{ab}$ & $100 \mathrm{a}$ & $100 \mathrm{a}$ \\
\hline$-13^{\circ} \mathrm{C}$ & $3 d$ & $18 \mathrm{~b}$ & $18 \mathrm{bcd}$ & $92 \mathrm{a}$ & $100 \mathrm{a}$ & $100 \mathrm{a}$ \\
\hline$-14^{\circ} \mathrm{C}$ & $8 \mathrm{c}$ & $77 \mathrm{ab}$ & $31 \mathrm{bc}$ & $100 \mathrm{a}$ & $100 \mathrm{a}$ & $100 \mathrm{a}$ \\
\hline$-15^{\circ} \mathrm{C}$ & $49 \mathrm{~b}$ & $77 \mathrm{ab}$ & $36 \mathrm{bc}$ & $100 \mathrm{a}$ & $100 \mathrm{a}$ & $100 \mathrm{a}$ \\
\hline$-16^{\circ} \mathrm{C}$ & $97 \mathrm{ab}$ & $100 \mathrm{a}$ & $87 \mathrm{~b}$ & $100 \mathrm{a}$ & $100 \mathrm{a}$ & $100 \mathrm{a}$ \\
\hline$-17^{\circ} \mathrm{C}$ & $99 \mathrm{ab}$ & $100 \mathrm{a}$ & $95 \mathrm{ab}$ & $100 \mathrm{a}$ & $100 \mathrm{a}$ & $100 \mathrm{a}$ \\
\hline$-18^{\circ} \mathrm{C}$ & $100 \mathrm{a}$ & $100 \mathrm{a}$ & $100 \mathrm{a}$ & $100 \mathrm{a}$ & $100 \mathrm{a}$ & $100 \mathrm{a}$ \\
\hline$-19^{\circ} \mathrm{C}$ & $100 \mathrm{a}$ & $100 \mathrm{a}$ & $100 \mathrm{a}$ & $100 \mathrm{a}$ & $100 \mathrm{a}$ & $100 \mathrm{a}$ \\
\hline$-20^{\circ} \mathrm{C}$ & $100 \mathrm{a}$ & $100 \mathrm{a}$ & $100 \mathrm{a}$ & $100 \mathrm{a}$ & $100 \mathrm{a}$ & $100 \mathrm{a}$ \\
\hline$-21^{\circ} \mathrm{C}$ & $100 \mathrm{a}$ & $100 \mathrm{a}$ & $100 \mathrm{a}$ & $100 \mathrm{a}$ & $100 \mathrm{a}$ & $100 \mathrm{a}$ \\
\hline$-22^{\circ} \mathrm{C}$ & $100 \mathrm{a}$ & $100 \mathrm{a}$ & $100 \mathrm{a}$ & $100 \mathrm{a}$ & $100 \mathrm{a}$ & $100 \mathrm{a}$ \\
\hline
\end{tabular}


Alnuaimi and Prrlak / Selcuk J Agr Food Sci, (2019) 33 (1), 26-36

Table 2

The lowest daily temperatures between January and May in Konya Province for many years.

\begin{tabular}{|c|c|c|c|c|}
\hline \multirow{2}{*}{ Dates } & \multicolumn{4}{|c|}{ Daily minimum temperatures $\left({ }^{\circ} \mathrm{C}\right)$} \\
\hline & January & February & March & April \\
\hline 1 & -23.9 & -18.7 & -15.8 & -6.6 \\
\hline 2 & -22.4 & -20.8 & -15.5 & -5.7 \\
\hline 3 & -21.8 & -19.1 & -16.4 & -5.4 \\
\hline 4 & -23.2 & -22.0 & -12.0 & -5.0 \\
\hline 5 & -27.8 & -23.4 & -15.0 & -5.7 \\
\hline 6 & -28.2 & -26.5 & -14.6 & -4.0 \\
\hline 7 & -23.1 & -23.8 & -15.4 & -6.0 \\
\hline 8 & -25.7 & -25.0 & -11.9 & -5.7 \\
\hline 9 & -21.5 & -19.1 & -10.6 & -4.6 \\
\hline 10 & -19.5 & -19.4 & -9.9 & -7.4 \\
\hline 11 & -16.5 & -26.2 & -12.8 & -8.6 \\
\hline 12 & -16.2 & -18.5 & -10.0 & -8.6 \\
\hline 13 & -16.6 & -15.0 & -11.1 & -4.9 \\
\hline 14 & -18.1 & -17.0 & -11.6 & -5.2 \\
\hline 15 & -20.5 & -13.9 & -11.4 & -3.7 \\
\hline 16 & -17.5 & -13.6 & -11.8 & -6.0 \\
\hline 17 & -14.5 & -12.0 & -9.5 & -2.0 \\
\hline 18 & -22.8 & -10.8 & -7.5 & -3.4 \\
\hline 19 & -19.2 & -12.9 & -9.3 & -3.6 \\
\hline 20 & -19.7 & -11.9 & -10.0 & -2.0 \\
\hline 21 & -18.0 & -15.0 & -8.0 & -1.2 \\
\hline 22 & -18.2 & -14.2 & -7.5 & -3.1 \\
\hline 23 & -20.0 & -12.6 & -12.6 & -3.0 \\
\hline 24 & -22.0 & -18.0 & -7.8 & -5.2 \\
\hline 25 & -25.8 & -22.8 & -10.4 & -1.5 \\
\hline 26 & -23.7 & -14.0 & -7.3 & -1.2 \\
\hline 27 & -21.0 & -19.5 & -7.5 & -1.0 \\
\hline 28 & -18.0 & -19.0 & -7.4 & -1.5 \\
\hline 29 & -18.4 & -10.6 & -7.9 & -1.7 \\
\hline 30 & -19.4 & - & -10.4 & -1.3 \\
\hline 31 & -21.2 & - & -6.0 & - \\
\hline
\end{tabular}


Alnuaimi and Prrlak / Selcuk J Agr Food Sci, (2019) 33 (1), 26-36

Table 3

The lowest daily temperatures between January and May for 2018 in Konya Province.

\begin{tabular}{|c|c|c|c|c|}
\hline \multirow{2}{*}{ Dates } & \multicolumn{4}{|c|}{ Daily minimum temperatures $\left({ }^{\circ} \mathrm{C}\right)$} \\
\hline & January & February & March & April \\
\hline 1 & -1.4 & -6.6 & -0.2 & 3.8 \\
\hline 2 & -3.8 & -6.8 & -2.7 & 5.9 \\
\hline 3 & -1.5 & -0.6 & 4.6 & 1.3 \\
\hline 4 & 0.2 & 1.1 & 5.1 & 0.4 \\
\hline 5 & -1.1 & 2.6 & 3.7 & 2.1 \\
\hline 6 & -0.2 & -0.8 & 6.0 & 2.2 \\
\hline 7 & -5.1 & -1.6 & 7.5 & 3.0 \\
\hline 8 & -0.4 & 4.2 & 6.5 & 7.4 \\
\hline 9 & -0.2 & 5.1 & 6.2 & 6.3 \\
\hline 10 & -0.8 & 3.1 & -0.2 & 6.5 \\
\hline 11 & -1.4 & 1.0 & 0.5 & 4.8 \\
\hline 12 & 3.9 & 0.5 & 2.8 & 7.9 \\
\hline 13 & -0.6 & 2.0 & 1.6 & 8.7 \\
\hline 14 & 1.9 & -1.2 & 4.0 & 7.6 \\
\hline 15 & -0.9 & 0.2 & 4.6 & 9.5 \\
\hline 16 & -3.2 & 1.2 & 1.7 & 7.4 \\
\hline 17 & 0.2 & 3.9 & 1.4 & 2.8 \\
\hline 18 & 1.4 & 2.1 & 4.0 & 6.1 \\
\hline 19 & -2.6 & -4.8 & 2.8 & 9.5 \\
\hline 20 & -7.6 & -0.1 & 3.7 & 7.8 \\
\hline 21 & -2.5 & 3.1 & 1.1 & 5.0 \\
\hline 22 & 1.5 & -1.4 & 1.5 & 2.1 \\
\hline 23 & 2.1 & 1.6 & 7.0 & 1.8 \\
\hline 24 & -1.1 & -0.7 & 12.0 & 5.0 \\
\hline 25 & -5.0 & 2.1 & 0.1 & 5.2 \\
\hline 26 & -5.1 & 2.0 & 1.7 & 12.6 \\
\hline 27 & -2.8 & 1.7 & 2.0 & 10.6 \\
\hline 28 & -1.4 & 1.9 & 3.6 & 13.6 \\
\hline 29 & - & - & 7.4 & 9.6 \\
\hline 30 & - & - & 3.9 & 9.5 \\
\hline 31 & - & - & -1.2 & - \\
\hline
\end{tabular}

Table 4

Determination of total amount of cherry buds, bound, free water and dry matter (\%).

\begin{tabular}{lcccc}
\hline Period date & 29.01 .2018 & 19.02 .2018 & 05.03 .2018 & 19.03 .2018 \\
\hline Free Water \% & $76.91 \mathrm{c}$ & $78.28 \mathrm{c}$ & $83.10 \mathrm{~b}$ & $96.30 \mathrm{a}$ \\
Bound Water \% & $9.69 \mathrm{a}$ & $8.27 \mathrm{a}$ & $4.39 \mathrm{~b}$ & $1.38 \mathrm{c}$ \\
Total Water \% & $86.60 \mathrm{~b}$ & $86.55 \mathrm{~b}$ & $87.50 \mathrm{~b}$ & $97.74 \mathrm{a}$ \\
Dry matter \% & $13.39 \mathrm{a}$ & $13.44 \mathrm{a}$ & $12.50 \mathrm{a}$ & $2.25 \mathrm{~b}$ \\
\hline
\end{tabular}


Table 5

Nutrient quantities in sour cherry flower buds at different dates.

\begin{tabular}{lcccccc}
\hline Nutrients & 29.01 .2018 & 20.02 .2018 & 06.03 .2018 & 20.03 .2018 & 05.04 .2018 & 20.04 .2018 \\
\hline $\mathrm{N}(\%)$ & $2.75 \mathrm{a}$ & $2.76 \mathrm{a}$ & $2.66 \mathrm{ab}$ & $2.45 \mathrm{ab}$ & $2.50 \mathrm{ab}$ & $2.31 \mathrm{~b}$ \\
$\mathrm{P}(\mathrm{mg} / \mathrm{kg})$ & $2540 \mathrm{c}$ & $3012 \mathrm{~b}$ & $2979 \mathrm{~b}$ & $3355 \mathrm{a}$ & $2544 \mathrm{c}$ & $2715.5 \mathrm{c}$ \\
$\mathrm{K}(\mathrm{mg} / \mathrm{kg})$ & $20134 \mathrm{c}$ & $22243 \mathrm{~b}$ & $22350 \mathrm{~b}$ & $24350 \mathrm{a}$ & $21220 \mathrm{bc}$ & $21560 \mathrm{bc}$ \\
$\mathrm{Ca}(\mathrm{mg} / \mathrm{kg})$ & $11230 \mathrm{~b}$ & $11320 \mathrm{~b}$ & $13450 \mathrm{a}$ & $12340 \mathrm{ab}$ & $12300 \mathrm{ab}$ & $11800 \mathrm{~b}$ \\
$\mathrm{Mg}(\mathrm{mg} / \mathrm{kg})$ & $1890 \mathrm{~b}$ & $2034 \mathrm{~b}$ & $2120 \mathrm{ab}$ & $2340 \mathrm{a}$ & $2310 \mathrm{a}$ & $2300 \mathrm{a}$ \\
$\mathrm{Fe}(\mathrm{mg} / \mathrm{kg})$ & $134 \mathrm{c}$ & $145 \mathrm{bc}$ & $167 \mathrm{a} \mathrm{b}$ & $176 \mathrm{a}$ & $175 \mathrm{a}$ & $178 \mathrm{a}$ \\
$\mathrm{Mn}(\mathrm{mg} / \mathrm{kg})$ & $34.45 \mathrm{c}$ & $35.76 \mathrm{bc}$ & $36.74 \mathrm{bc}$ & $45.65 \mathrm{a}$ & $40.21 \mathrm{~b}$ & $38.77 \mathrm{bc}$ \\
$\mathrm{Zn}(\mathrm{mg} / \mathrm{kg})$ & $28.76 \mathrm{~b}$ & $28.44 \mathrm{~b}$ & $33.23 \mathrm{ab}$ & $34.35 \mathrm{a}$ & $36.54 \mathrm{a}$ & $32.24 \mathrm{ab}$ \\
$\mathrm{Cu}(\mathrm{mg} / \mathrm{kg})$ & $44.56 \mathrm{~d}$ & $47.68 \mathrm{~cd}$ & $55.34 \mathrm{a}$ & $53.44 \mathrm{ab}$ & $52.23 \mathrm{bc}$ & $48.76 \mathrm{~cd}$ \\
$\mathrm{~B}(\mathrm{mg} / \mathrm{kg})$ & $12.33 \mathrm{~b}$ & $13.05 \mathrm{ab}$ & $12.24 \mathrm{~b}$ & $13.43 \mathrm{ab}$ & $14.32 \mathrm{ab}$ & $15.46 \mathrm{a}$ \\
$\mathrm{S}(\mathrm{mg} / \mathrm{kg})$ & $2012 \mathrm{a}$ & $2033 \mathrm{a}$ & $2045 \mathrm{a}$ & $2320 \mathrm{~b}$ & $2243 \mathrm{~b}$ & $2210 \mathrm{~b}$ \\
\hline
\end{tabular}

Table 6

Carbohydrate, protein and proline amounts of sour cherry buds on different dates.

\begin{tabular}{lcccccc}
\hline Period Date & $29 / 01$ & $19 / 02$ & $05 / 03$ & $19 / 03$ & $04 / 04$ & $19 / 04$ \\
\hline Carbohydrate $(\mathrm{mg} / \mathrm{g})$ & $4.232 \mathrm{a}$ & $4.063 \mathrm{~b}$ & $3.933 \mathrm{c}$ & $3.542 \mathrm{e}$ & $3.516 \mathrm{e}$ & $3.768 \mathrm{~d}$ \\
Protein $(\mathrm{mg} / \mathrm{g})$ & $1.423 \mathrm{a}$ & $1.409 \mathrm{~b}$ & $1.346 \mathrm{c}$ & $1.315 \mathrm{~d}$ & $1.236 \mathrm{e}$ & $1.215 \mathrm{e}$ \\
Proline $(\mathrm{mg} / \mathrm{g})$ & 2.573 & 2.526 & 2.550 & 2.566 & 2.589 & 2.590 \\
\hline
\end{tabular}

\section{Conclusions}

Differences in fatal temperatures and resistance to cold were observed in different developmental stages. The observed damage is highly dependent on the development stages of the flower bud. It has been observed that the buds have increased sensitivity to low temperatures. Flower tolerance is influenced by early flower bud stage and temperature fluctuation during flowering, while hot conditions increase flower sensitivity, low temperature reduces this requirement. Although the determination of the maximum durability can be obtained genetically, it is possible to explain the changes in strength; As a result of the strong climatic effect, more and more years of observation are needed. Flower buds are known to survive the cold damage that kills the tree; resistance varies widely throughout the year (Proebsting, 1982).

The softening, hardening time, fluctuations in the resistance of the flower bud were supported by observations in the middle of winter, according to changes in ambient air temperature (Andrews and Proebsting Jr, 1987). The deadly temperature for the sour cherry flower buds was $-16^{\circ} \mathrm{C}$, while the unopened flower bud increased rapidly to $-11^{\circ} \mathrm{C}$. Extremely low temperatures, which may occur during the rest period in the economic sour cherry cultivation in Konya city center, can damage the cherry flower buds. Therefore, it is advisable to avoid hollow areas where cold air is deposited as much as possible while closing gardens are preferred, and as far as possible, prefer protected areas.

\section{Aknowledgement}

This research was prepared from the Master of Science thesis (in Selcuk University) entitled "Kütahya
Vişne Çeşidinde Tomurcuk ve Çiçeklerin Soğuğa Dayanılılık Düzeylerinin Belirlenmesi"

\section{References}

Andrews P, Proebsting JE (1987). Effects of temperature on the deep supercooling characteristics of dormant and deacclimating sweet cherry flower buds, Journal of the American Society for Horticultural Science, 112 (13), 334-340.

Anonim (2018). FAO, www.fao.org, Erişim tarihi: 31.12.2018

Ashraf M, Wu L (1994). Breeding for salinity tolerance in plants, Critical Reviews in Plant Sciences, 13 (1), 17-42.

Ashworth E (1983). The freezing of water in woody tissues of apricot and peach and the relationship to freezing injury, J. Am. Soc. Hortic. Sci., 108, 299303.

Aslantaş R, Karakurt H, Karakurt Y (2010). Bitkilerin düşük sıcaklıklara dayanımında hücresel ve moleküler mekanizmalar, Atatürk Üniversitesi Ziraat Fakültesi Dergisi, 41 (2), 157-167.

Aslantaş R, Güleryüz M, Turan M (1999). Some chemical contents of selected almond (Prunus amygdalus Batsch.) types. XI. Grempa Meeting on Pistacios and Almonds, Univ. of Harran, Faculty of Agric.Pistacio Research and Application Center 1-4 September 1999, Ş.Urfa (Turkey), , p: 347-350.

Bartolini S, Zanol G, Viti R (2001). The cold hardiness of flower buds in two apricot cultivars, XII International Symposium on Apricot Culture and Decline 701, 141-146.

Bartolozzi F, Fontanazza. G (1999). Assessment of frost tolerance in olive (Olea europaea L.), Scientia Horticulturae, 81 (3), 309-319. 
Bates L, Waldren R, Teare I (1973). Rapid determination of free proline for water-stress studies, Plant and Soil, 39 (1), 205-207.

Bolat I (1993). The relationship between frost resistance and seasonal changes in carbohydrate contents in flower buds in apricot (cvs. Salak and Tebereze), $\mathrm{X}$ International Symposium on Apricot Culture 384, 323-328.

Brasford M (1976). A rapid and sensitive method for quantitation of microgram quantities of protein utilizing the principle of protein-dye binding, Anal. Biochem. 72, 248-254.

Buchner O, Neuner G (2011). Winter frost resistance of Pinus cembra measured in situ at the alpine timberline as affected by temperature conditions, Tree physiology, 31 (11), 1217-1227.

Burak M (1989). Marmara Bölgesinde Yetiştirilen Önemli Bazı Şeftali Çeşitlerinin Dona Dayanımları Üzerinde Araştırmalar (Basılmamış Doktora Tezi) Uludağ Üniv, Bahçe Bitkileri Bölümü, Bursa.

Daniels L, Hanson RS, Phillips JA (2007). Chemical analysis, In: Methods for General and Molecular Microbiology, Third Edition, Eds: American Society of Microbiology, p. 462-503.

Demirel H (1997). Erzincan Ovası'nda seçilen and yetiştirilen bazı kayısı çeşitleri ve zerdali tiplerinin dona dayanımları üzerine bir araştırma, Atatürk Üniversitesi Fen Bilimleri Enstitüsü Doktora Tezi, Erzurum.

Ertürk Y, Güleryüz M (2007). Erzincan Koşullarında Bazı Yerli ve Yabancı Kayısı Çeşitlerinin Düşük Sicaklıklara Dayanım Derecelerinin Belirlenmesi (2003-2004 Dönemi), Tarım Bilimleri Dergisi, 13 (2), 128-136.

Felipe AJ (1977). Phenological States of Almond (In Italian). Bari. p., Proceedings of the Third GREMPA Colloquium, 101-103.

Guy CL (1990). Cold acclimation and freezing stress tolerance: role of protein metabolism, Annual review of plant biology, 41 (1), 187-223.

Hao W, Arora R, Yadav AK, Joshee N (2009). Freezing tolerance and cold acclimation in guava (Psidium guajava L.), HortScience, 44 (5), 1258-1266.

Hare P, Cress W (1997). Metabolic implications of stress-induced proline accumulation in plants, Plant Growth Regulation, 21 (2), 79-102.

Iezzoni A, Hamilton R (1985). Differences in spring floral bud development among sour cherry cultivars, HortScience (USA), 20 (5), 915-916.

Kalberer SR, Wisniewski M, Arora R (2006). Deacclimation and reacclimation of cold-hardy plants: current understanding and emerging concepts, Plant Science, 171 (1), 3-16.

Küden A, Paydaş S, Kaşka N, İmrak B (1998). Bazı Ilıman İklim Meyve Tür ve Çeşitlerinin Soğuğa Dayanıklılığı Üzerinde Çalışmalar, J Agric Forestry, 22 (2), 101-110.
Leece DR, Gilmour AR (1974). Diagnostic leaf analysis for stone fruit, 2. Seasonal changes in the leaf composition of peach, Australian Journal of Experimental Agriculture and Animal Husbandry, 14(71), 822-827.

Levitt J (1980). Responses of Plants to Environmental Stresses. 2nd ed. Academic Press, New York, 2, 607.

Litvinova OH, LRP (1974). Winter spring development of the flower buds in apricot and their winter hardiness, Plant Breeding Abst, 47 (2), 1567.

Mertens D (2005). AOAC official method 975.03, Metal in Plants and Pet Foods. Official Methods of Analysis, 18th edn. Horwitz, W., and GW Latimer,(Eds), 3-4.

Nybom H (1992). Freeze damage to flower buds of some apple cultivars, Journal of horticultural science, 67 (2), 171-177.

Özçağıran R, Ünal A, Özeker E, İsfendiyaroğlu M (2003). Ilıman İklim Meyve Türleri,(Sert Çekirdekli Meyveler, Cilt-I.), Ege Üniv, Ziraat Fak. Yayınlar1, 553.

Palonen P (1999). Relationship of seasonal changes in carbohydrates and cold hardiness in canes and buds of three red raspberry cultivars, Journal of the American Society for Horticultural Science, 124 (5), 507-513.

Pearce RS (2001). Plant freezing and damage, Annals of Botany, 87 (4), 417-424.

Pirlak L, Eşitken A (2004). Salinity effects on growth, proline and ion accumulation in strawberry plants, Acta Agriculturae Scandinavica, Section B-Soil \& Plant Science, 54 (3), 189-192.

Pramsohler M, Neuner G (2013). Dehydration and osmotic adjustment in apple stem tissue during winter as it relates to the frost resistance of buds, Tree physiology, 33 (8), 807-816.

Proebsting EL (1982). Cold resistance of stone fruit flower buds, Washington State University Cooperative Extension, $\mathrm{p}$.

Puhakainen T (2004). Physiological and molecular analyses of cold acclimation of plants., Department of Biological and Environmental Sciences, Genetics Faculty of Biosciences, University of Helsinki, Finland, 194.

Quamme H (1983). Relationship of air temperature to water content and supercooling of overwintering peach flower buds [Prunus persica, exotherm analyses, freezing resistance, winter hardiness], Journal American Society for Horticultural Science, 108, 697-701.

Reig G, Iglesias I, Miranda C, Gatius F, Alegre S (2013). How does simulated frost treatment affect peach [Prunus persica (L.)] flowers of different cultivars from worldwide breeding programmes?, Scientia Horticulturae, 160, 70-77. 
Scebba F, Sebastiani L, Vitagliano C (1998). Changes in activity of antioxidative enzymes in wheat (Triticum aestivum) seedlings under cold acclimation, Physiologia Plantarum, 104 (4), 747-752.

Smallwood M, Bowles DJ (2002). Plants in a cold climate, Philosophical Transactions of the Royal Society of London B: Biological Sciences, 357 (1423), 831-847.

Smirnoff N (1995). Environment and plant metabolism: flexibility and acclimation, BIOS Scientific publishers, $\mathrm{p}$.

Tamássy I, Zayan M (1981). Critical temperatures in winter (after rest period) and in spring (at blooming time) for fruit buds and open flowers of some apricot varieties from different groups, VII Symposium on Apricot Culture and Decline 121, 63-68.

Tuik (2018). www.tuik.gov.tr.

Westwood MN (1993). Temperate-Zone Pomology: Physiology and Culture., Timber Press, Madison, 536.

Wheeler J, Hoch G, Cortés AJ, Sedlacek J, Wipf S, Rixen C (2014). Increased spring freezing vulnera- bility for alpine shrubs under early snowmelt, Oecologia, 175 (1), 219-229.

Xin Z (1998). Eskimo1 mutants of Arabidopsis are constitutively freezing-tolerant, Proceedings of the National Academy of Sciences, 95 (13), 7799-7804.

Xin Z, Browse J (2000). Cold comfort farm: the acclimation of plants to freezing temperatures, Plant, Cell \& Environment, 23 (9), 893-902.

Yelenosky G (1979). Accumulation of free proline in citrus leaves during cold hardening of young trees in controlled temperature regimes, Plant physiology, 64 (3), 425-427.

Yeo A, Flowers T (1989). Breeding for salt tolerance, Plants under Stress: Biochemistry, Physiology and Ecology and Their Application to Plant Improvement, 39, 217.

Yigit D, Güleryüz M (1995). Farklı Doz ve Derinlikte Uygulanan Potasyum Sülfat Gübresinin Kütahya Vişne Çeşidinin Soğuğa Dayanımına Etkisi Üzerinde Bir Araştırma, , Türkiye II Ulusal Bahce Bitkileri Kongresi, Cilt;1, 253-257. 